【論 文】

\title{
戸別所得補償制度下での新たな転作対応
}

一新渴県の事例一

伊藤亮司

(新潟大学譨学部)

\section{A Case Study of New Production Adjustment System under Direct Payment Policy for Individual Income Compensation}

\author{
Ryoji ITO (Niigata University)
}

In Niigata, Most farmers are strongly motivated to participate in the direct payment policy for the individual income compensation. As background, I think it is due to poor sales of rice and sense of crisis to be reduced the allocation area. But a few offenders can have significant impact upon the market, because the price of rice produced in Niigata is the highest and the discount in Nigata will have big impact on other regions. So, embracing strategy is required for non-cooperative farmers, raising the level of direct payments amount, incentives for non-rice crops, development of the new demand, etc.

In such, some characteristic responses are

\section{1. 課題の限定}

本論文では，米単作地帯の典型である新舄県におけ る戸別所得補賲制度への対応について, 特に生産調 整：転作対応の面から整理することを目的とする ${ }^{\prime}$. ただし，「新たな転作対応」について，新潟での動き を端的に結論づければ，他作物への「転換」はすぐに は進まず，稻作単作のままというのが実情であり，特 に, 戸別所得補償制度の開始を契機とした短期的な動 きとしては，「コメ単作の維持」あるいは，「（非主 progress.

It is intended for new applications of rice, for fine powder, feed, fuel. In addition, the needs for domestic rice is increased, under the obligation to display the origin of raw materials policy, and the needs for imported rice "Minimum Access" have been no longer popular.

As a result, the rice production area is not reduced. But the establishment of these foundations will contain some uncertainties.

The price level of the rice of the new applications is extremely low and below the cost. It is dependent on the direct payment subsidies.

食用の) コメによる転作・生産調整」が進展する. 野 菜や果樹等の園芸作人の転換は通常5～10年以上かか ることもあり，短絡的に「戸別所得補償制度の作用」 を判断するのは早計だろうが, 戸別所得補償制度で は，てその他作物」として細々と支援されることとな った点は指摘しておかねばならない. 新舄でのこれら 園芸作については, 平成15から平成21年産までの間に 作付面積は微增（105ha增），また果樹作付は急应大 (921ha增) といずれも健䦚しているが2)，これは， 
国レベルの政策とともに県や市町村等で取り組ま れた長年に渡る振興策の成果という面も強い. そこ で, 本論では，国の政策である戸別所得補償制度を 念頭に，むしろ「コメによる転作」に至る論理を整 理することとする.

\section{2. 新潟における危機感一米洒下落と生産目標数量 配分の縮小}

さて, 新獡における近年のコメをめぐる情勢は厳 しさを增してきた，平成16年産より「売れるコメ づくり」を標榜して開始された都道府睤別生産目標 数量の配分では, 新潟県は前半期においては増加傾 向を見せ，好調な滑り出しとなった. 県内における 市町村への配分においても需要実績等「売れるコ メ」に配虑した傾斜配分ルールを策定し「改革」 路線を貫微していったが，増えるパイの配分であった ため県内市町村段階において「転作強化」が迫られる ことはあまりなかった.

ところが，消費不況下での高洒格帯市場の縮小と 「新舄米の高洒格ゆえの販売難」が表面化する中で， 価格低下と「肘壳残」が翌年の生産目標数量減につな がるダブルパンチが県下を䒾う3)。．その状㫛のなか での「実績等」に基づく市町村別配分ルールの徹底は, 地域による強弱を伴いつつ，転作強化=主食用米作付 面積の縮小を迫られる状㫛を生む．具体的には，平成 20年産米からの対応である.

この間の各県の生産目標数量の推移を示したのが 図 1 である. 平成16年産米を100とした場合，新潟の 平成19年産米までは，基本的に搪大べ一スで推移し， その後，急速に数量を堿少させているのが見て取れ る. 他県のより早く，あるいは前半の拡大がみられな いまま減少べースに至った展開とは様相が異なり，そ の分，「転作対応」は遅れることになる。

トップ産地である新獡県産米の価格の低下は, 玉突 き的に他県産米一の価格低下の起点となる．24,000円 $160 \mathrm{~kg}$ 台を維持する「魚沼コシヒカリ」は若干独自の 動きを示す（転作対応としてみれば価格差の大きい非 主食用人の転換困難として作用）が，新舄一般コシヒ カリを筆頭に，二番手の北陸·東北米が連動，玉突き 的に価格を低下させ,かつ価格差を維小させてきた ${ }^{4)}$.

新潟としては，值引き販売により「売り切り」をし て, 翌年の生産目標数量の縮小を少しでも緩和するこ

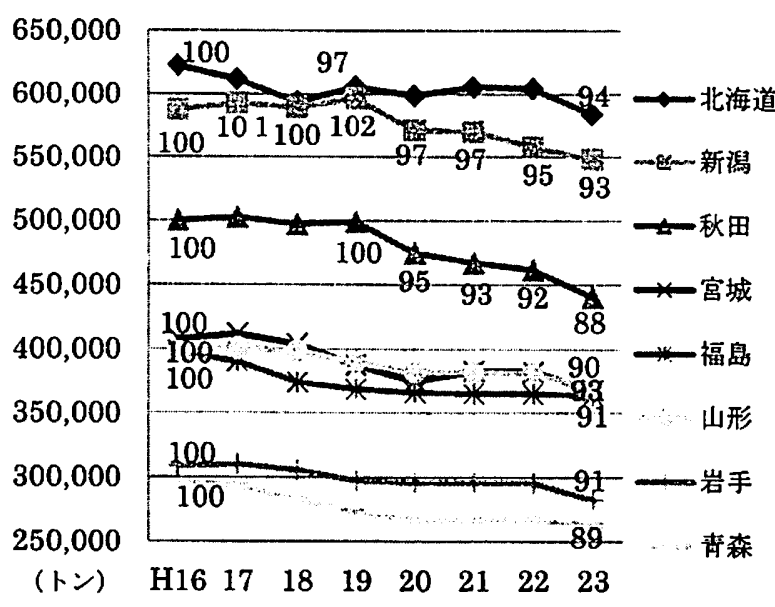

图 1 都道府県別の生産目標数量の推移 㗄料:晨水省総合食料局『都道府斯別の生産目標数量』.

とと,一定の価格維持を図り市場全体の值崩れや生産 者への清算価格を少しでも維持することの見合で難 しいかじ取りを迫られた。值引き販売の気運は, 平成 19 年産米および平成 21 年産において高まり, 平成 19 年産米においては, 結局, 70,113 トンもの政府売 り渡しにより最終的には回避されたが，この時点で, もはや新潟県産コシヒカリの従来市場である小売洒 格 4,000 円/10kg 以上の高価格带市場は 20 万 $\mathrm{t}$ が限 度であることが明膫となってきた. 平成 21 年産米に おいては，4 月末時点で前年対比，魚沼コシヒカリが $78 \%$ ，新潟一般コシヒカリが $88 \%$ しか販売が進まず, 5 月以降, $1,500 \sim 2,000$ 円 $/ 60 \mathrm{~kg}$ の值引き販売によ り, なりふり棒かない「売り切り」を仕掛けることに なる.

その後, 平成 22 年産米スタート時点でも，その延 長で 15,000 円 $/ 60 \mathrm{~kg}$ (新潟一般コシ) の低価格販売 で攻勢をかけたこと，また，新舄県は作付目標面積配 分ルールに「新品揃え枠」を設定して，コシヒカリか ら「こしいぶき」への品種構成シフトを図り，コシヒ カリの作付割合を $75 \%$ まで落とし，その分拡大した 「こしいぶき」を業務用需要への対応商品として，実 質的な低俩格・值引き販売を強化している. 平成 22 年産「こしいぶき」の販売価格は県外業務用を念頭に 「他県産競合銘柄」を意識した 12,500 円 $/ 60 \mathrm{~kg}$ (前 年比マイナス 1,600 円）とした. これは，東北産米の 肘売価格と同等の価格設定であり，東北産米のシェア 萑取を狙ったものである.これまで、全国共販の維持 
のために低価格肘売を極力避けてきた新鸱の踏ん張り もここまでが限界だったといえる。

このような状況の下での, 新潟県の課題は, まず第 一義的に, コシヒカリの「売れる」低価格販売への対 応，および業務用・加工用等の新たな販路構筑のため の非コシヒカリ生産への誘導であった.そのため大豆, あるいは園芸産品への対応はその次の課題となりが ちである5)。具体的には，新蕮県のコメ政策改革基 本方針において「売れるコメづくり」への課題として, (1)食味・品質の確保に向けた高品質・良食味・安定 生産の推隹, (2)㻴境保全型農業の推進, (3)安全·安 心な農産物の提供, (4)生産コスト低减の推進が挙げ られ，また，非コシヒカリへの誘導として，(1)生産 目標数量配分における「品揃え枠」活用，(2)21 年産 より区分清算となった「早期契約」枠の $30 \%$ をこ しいぶき等」へ，(3)銘柄誘導奨励金 525 円/60kg 等の 助成措置が取られた.このような状況のなかで, 主食 用米に 1.5 万円十変動部分, 加工用米に 2 万円, 新規 需要米に 8 万円の支援を内容とする「戸別所得補償 制度」が導入されたのである.

\section{3. 戸別所得補償モデル対策への加入動向と転作対応}

表 1 に示すように, 新禈県の戸別所得補䐝制度（米 対策) への参加状况は, 件数で81.6\%, 面積で $85.6 \%$ に 達しており，これは全国值と比べると，高い值を示し ている. しかも当初の加入申請は73,112件と平成21年 産水稲共済引き受け者の $90 \%$ に及んでおり，参加意欲 という点では非常に高、状况であった. 実際の受付者 は，条件を满たした66,571件，また，支払対象者は64， 638件だったが，その結果を踏まえた平成23年産におけ る申請者数も，前年度支払いを受けた者以上に多く， 制度への参加意欲は衰えていない。

それとともに，制度加入の条件となる生産調整への 参加およびそれに よる水稻作付面糟 については, 表 2 通り, コメ改革前半 における過剩作付 増，後半における 減，更に戸別所得補 侻下で再び過翻作 付が增加している
表 1 新渭県における (米) 戸別所得補儧制度への参加状況

\begin{tabular}{|c|c|c|}
\hline & 件数 & 面棋 (ha) \\
\hline 水稲共済引受け者 (H21 産) & 81,539 & 108,967 \\
\hline 米戸別䋠䖵モデル (H22) 申譛者 & 73,112 & - \\
\hline 米戸別補供モデル (H22) 受付者 & 66,571 & 93,235 \\
\hline 加入割合 (\%) & 81.6 & 85.6 \\
\hline 米戸別補供モデル (H22) 支払者 & 64,638 & 85,568 \\
\hline (米) 所得㭪供対策 (H23) 申請者 & 65,544 & - \\
\hline 加入害哈 (\%) & 80.4 & - \\
\hline
\end{tabular}

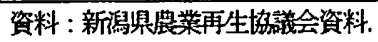

表 2 新潟罚におけるコメ過剩作付面積の推移

\begin{tabular}{|c|c|c|c|c|}
\hline 年産 & $\begin{array}{l}\text { 生産目標面稹 } \\
\text { 換算值 (ha) }\end{array}$ & $\begin{array}{c}\text { 実作付面榬 } \\
\text { (ha) }\end{array}$ & $\begin{array}{l}\text { 過剩作付 } \\
\text { 面皘 (ha) }\end{array}$ & $\begin{array}{c}\text { 生珄目標に } \\
\text { 占める割合 } \\
(\%)\end{array}$ \\
\hline H16 & 110,651 & 114,771 & 4,120 & 3.8 \\
\hline 17 & 111,881 & 115,834 & 3,953 & 3.6 \\
\hline 18 & 110,254 & 114,773 & 4,519 & 4.1 \\
\hline 19 & 110,763 & 115,553 & 4,790 & 4.3 \\
\hline 20 & 106,903 & 111,486 & 4,583 & 4.3 \\
\hline 21 & 106,948 & 111,167 & 4,219 & 3.9 \\
\hline 22 & 104,243 & 108,647 & 4,403 & 4.2 \\
\hline
\end{tabular}

資料 : 新獡県農莱再生協議会資料。

のが特徴である. 平成19年産までは, 生産目標数昌が 増加する中（販売が不調ではない全体状㫛のもと）で, 実作付面積はそれ以上に増加し，過㮃作付が却って增 えるという局面であったが，平成20年産・平成21年産 と逆転し，(販売不振を背景として）生産目標数量が 减るなかで実作付面積はそれ以上に減り，徐々にでは あるが過剩作付は縮小傾向にあった．それが平成22年 産（戸別所得補償制度を契機として）において，過剩 作付が再び面積およひ割合ともに堌加し，コメ回帰が 生じている.

表 3 は，このうち平成19年産以降の生産目標数量减 少局面での生産調整不参加者の中身を整理したもので ある. 前述の通り，平成19〜平成21まで過㮃作付面積 自体は縮小過程にあったものの，過剩作付を行う生産 者の数自体は増加しており，それは，20、以下のいわゆ 表 3 新潟県における生産調整の状況 単位: 者, \%

\begin{tabular}{|c|c|c|c|c|c|c|}
\hline & \multirow{2}{*}{$\begin{array}{l}\text { 方針参加 } \\
\text { 震業者数 }\end{array}$} & \multirow{2}{*}{$\begin{array}{c}\text { 方針不参加 } \\
\text { 農業者数 }\end{array}$} & 過剩作付 & \multicolumn{3}{|l|}{ 過剩作付 } \\
\hline & & & してない & している & うち 20a 未满 & $20 \mathrm{a}$ 以上 \\
\hline H19 年産 & 110,544 & 11,763 & 4,968 & 6,795 & 1,215 & 5,580 \\
\hline H20 年偟 & 108,101 & 10,328 & 2,681 & 7,647 & 1,793 & 5,854 \\
\hline H21 年産 & 106,156 & 10,722 & 2,419 & 8,303 & 1,819 & 6,484 \\
\hline \multirow{2}{*}{$\mathrm{H} 22$ 年産 } & 102,393 & 11,274 & 2,716 & 8,558 & 2,235 & 6,323 \\
\hline & $(90.1)$ & $(9.9)$ & $(2.4)$ & $(7.5)$ & $(2.0)$ & $(5.6)$ \\
\hline
\end{tabular}

資料 : 新獡県農林水産部農産園芸課資料。 
表4 県間調整枠の配分 (H21 年産)

\begin{tabular}{c|r|r|r}
\hline & \multicolumn{1}{|c|}{$\begin{array}{c}\text { 調整数盟 } \\
\text { (トン }\end{array}$} & \multicolumn{1}{c|}{$\begin{array}{c}\text { 調整後需要量 } \\
\text { (トン }\end{array}$} & \multicolumn{1}{c}{$\begin{array}{c}\text { 割合 } \\
(\%)\end{array}$} \\
\hline 小千谷 & 300 & 11,140 & 2.7 \\
魚沼 & 451 & 13,500 & 3.3 \\
南魚沼 & 1,524 & 24,477 & 6.2 \\
津南 & 695 & 7,485 & 9.3 \\
十日町 & 1,470 & 21,638 & 6.8 \\
新鼠市 & 400 & 111,754 & 0.4 \\
加茂市 & 200 & 5,612 & 3.6 \\
\hline
\end{tabular}

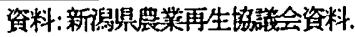

る飯米農家とともに，それを超える層にも広がりつつ あった，それに対して，戸別所得補償制度を契機とし た生産調整不参加者は飯米農家に集中し，むしろそれ 以上の規模層では過郵作付者の数を堿らしているのが 特徽的である. すなわち現下の新潟における生産調整 不参加者の增加は，飯米農家が制度の埒外に置力冯た ことによるものと判断される ${ }^{6)}$ ．ただし，平成22年度 からの新たな状㫛として，国のスキームによる県間調 整が成立せず, 平成21年産では5,040トンもの生産枠を 佐賀県から䝼入していたのが，県協議会同士の話し合 いで2,655トンへと半減したことにより，これまで県間 調整枠の配分により主食用米を追加生産していた市町 村では，不足する数量枠の分が一気に生産調整不参加 分として計上されることとなった. 表4で示すように, 特に配分量の占める割合の高い，津南町およひ南魚沼 市・十日町市の3市町（いずれも魚沼米産地）では，担 い手層を含めて生産調整加ら外れるケースが出てきて いる. これら魚沼の担い手に共通するのが，顧客が確 保された中で，販売量を減らす訳にいかず，短期的に は損をしてでも一定の生産を確保したい意问 とともに，围場整備事業の償罯金負担や水利 費負担を賄うためには，加工用米等では赤字 となってしまう高コスト構造》゙を持ち，主食 用米以外の選択肢がないことである.これら 目問語整枠の縮小に起因する「過㮃作付」は， 県内全域で200ha程度とのことであるが, 减ら された面積としては400haを超えており，過鄱 解消を図るには，県間調整への予算的措圈や （魚沼コシ水準の）主食用米との価格差補填 の積み增しによる加工用米・新規需要米等へ の誘導が課題となる.

次いで，大豆等の土地利用型の転作作目の 状況を示したのが表 5 おび図 2 である. 米

\begin{tabular}{|c|c|c|c|c|}
\hline 作物名 & H18 年産 & 20 & 21 & 22 \\
\hline 麦 & 400 & 432 & 387 & 382 \\
\hline 大豆 & 6,200 & 7,070 & 6,930 & 6,393 \\
\hline そば & 1,300 & 1,344 & 1,235 & - \\
\hline 米粉用米 & & 59 & 683 & 1,731 \\
\hline 飼料用米 & 300 & 10 & 14 & 859 \\
\hline WC S用稻 & & & 203 & 274 \\
\hline ハオ才绻料用米 & $\mathbf{0}$ & 280 & 280 & 317 \\
\hline 加工用米 & 5,100 & 5,255 & 5,516 & 7,453 \\
\hline 調整水田等不作付地 & 11,400 & - & 7,455 & 6,268 \\
\hline
\end{tabular}

凟料 : 新潟県農業再生協譐会资料。

以外の作付品目としては大豆が最重要なのは言うまで もないが，平成20年産をピークに作付面積が減少し， 戸別所得補償制度の前後においても500ha以上减少し ている．前述の通り，園芸品目は，平成16年から見れ ば，野菜微増，果樹抗大ではあるが，その拡大分は平 成19年産までの状況であり，その後は微减およひ微增 なので，他作物一の転換という意味では，戸別所得補 償の初年度はむしろ後退といって良い，また平成23年 産加は，水田利活用交付金に加之て，烟作物所得補 償交付金が助成されたため，大豆等は一定の回復が予 想されるが，平成22年産の場合，新舄の大豆平均収量 は146kg，等級としては3等〜特定加工用がメインなた め助成単価は，2２.5万円，水田利活用交付金 3.5 万円 を足しても5.5〜6万円の水淮にとどまる見込みであ る. ちなみに平成21年産の産地確立計画の大豆最高単 価は，全県平均で5万円程度といわれ，そのうち6万円 超が5/40市町村, 5.5万円超が15/40市町村であった.こ

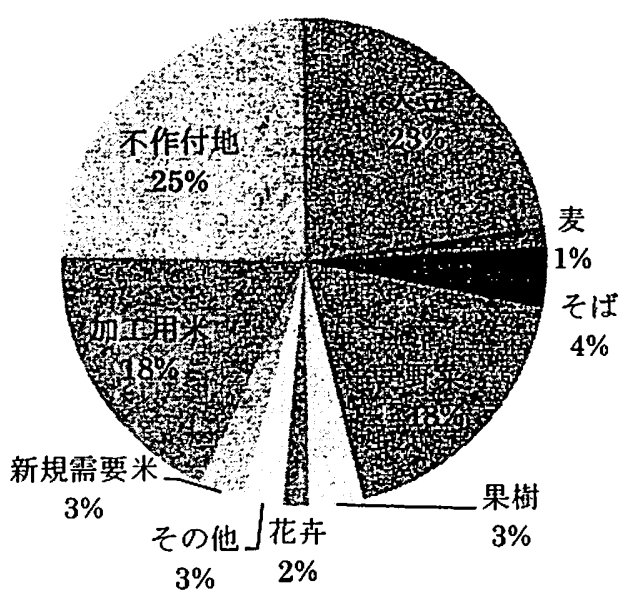

図 2 新潟䍒における水田転作の状況（H21産）

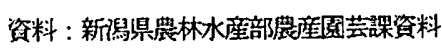


れらの市町村で条件悪化，その他の市町村でも，大 きな条件改善とはならないとすれば，大豆の生産拡大 は伸び悩恐恐れがある. 特に，気候条件等の問題で大 豆の平均収量が低く，そもそも転作作物として不向き な市町村 (平成22年の反収 $100 \mathrm{~kg}$ 以下: 系魝川市 $86 \mathrm{~kg}$ ・ 五泉市 $79 \mathrm{~kg}$ ・聖籠町 $79 \mathrm{~kg}$ ・阿賀町 $64 \mathrm{~kg}$ ・粟島浦村 $79 \mathrm{k}$ g) では，コメ以外の転作作目を見つけることが困難な ままである8)

\section{4. コメ作付面皘維持のための「コメによる転作」}

以上のように，他作目が伸び悩む中で，田本地面積 の8割以上を水稲作付が占め（『作物統計』平成22年）， 水稲単作地带を維持する新舄では，加工用米およびそ の後の平成20年産からの新規需要米の取り組みが加速 する. いわゆる「コメによる転作」である. 前出表 5 においても，平成22年産では，すでに加工用米+新規需 要米=1万ha超と，最大の「転作」作目である.

表 6 は，平成16年産米と平成 22 年産米の作付面積の 增减を生産目標数量の面積換算值および『作物統計』 上の実作付面積とで比較したものである. 平成19年産 米以降，生産目標数量が減らされ，平成 22 年には，全 県で平成16年産米の $95.6 \%$ にまで作付を制限されるこ ととなった. しかもそれは，配分面積の需要奉績に基 うく傾斜が加速することにより，地域間格差を伴って 進行する.

県北の村上市や中越の出雲崎町, 長岡市でかえって 配分増となる反面，五泉市や加茂市では，大幅な堿反 強化が必要となり, また魚沼地域や上越市は, 微瑊に とどまる.

しかし，上記のごとく大豆等の「他品目」への切り 替え条件の整わない市町村では，コメを作らざるを得 ない.そこで「コメによる転作」がはかられ，一部は 生産調整不参加による「過剩作付」を含めて，実際に は県計で9.3\%とコメの作付面櫝はほとんど減らず. 8 市町村では却ってコメの作付面積が増えている.

実作付面積と生産目標数量の差が大きい胎内市, 新 発田市, 五泉市, 新舄市, 加茂市, 見附市, 津南町は, いずれも特徵のある取り組みを行っている. 新規需要 米としては，侏新舄製粉を抱える胎内市およひ株斎藤 製粉を抱える新発田市が米粉用米の取り組みのトップ を走る. 五泉市は, 全農の輸出用米の供給, 加茂市お よび見附市はバイオエタノール米の取り組みを進め
表6 市町村別生産目標およひ実作付の变化率比較

\begin{tabular}{|c|c|c|c|}
\hline & $\begin{array}{c}\text { 生産目墂面稰 } \\
\text { の增减 }\end{array}$ & $\begin{array}{c}\text { 実作付面稙 } \\
\text { の增诚 }\end{array}$ & 差し引き \\
\hline 闗川村 & 98.4 & 99.9 & 1.5 \\
\hline 村上市 & 101.2 & $\underline{103.8}$ & 2.6 \\
\hline 聖䉁町 & 91.1 & 95.0 & 3.9 \\
\hline 胎内市 & 96.7 & 106.7 & $\underline{10.0}$ \\
\hline 新発田市 & 94.2 & 102.3 & $\underline{8.1}$ \\
\hline 阿贺野市 & 92.0 & 96.0 & 3.9 \\
\hline 五泉市 & 88.7 & 96.0 & 7.3 \\
\hline 阿驾町 & 91.7 & 93.2 & 1.4 \\
\hline 新鼠市 & 92.4 & 99.3 & $\underline{6.9}$ \\
\hline 弥彦村 & 95.7 & 97.5 & 1.7 \\
\hline 燕市 & 95.4 & 101.4 & 6.0 \\
\hline 田上町 & 92.1 & 98.8 & 6.7 \\
\hline 加茂市 & $\underline{88.8}$ & 95.9 & $\underline{7.1}$ \\
\hline 三条市 & 94.6 & 98.3 & 3.8 \\
\hline 見附市 & 93.1 & 102.1 & 8.9 \\
\hline 出雲渏町 & 100.9 & 92.4 & $\triangle 8.5$ \\
\hline 長岡市 & 101.6 & 95.6 & $\triangle 6.1$ \\
\hline ，诩村 & 97.2 & 92.9 & $\triangle 4.3$ \\
\hline 柏䗁市 & 91.5 & 89.6 & $\triangle 1.8$ \\
\hline 小千谷市 & 95.7 & $\underline{100.0}$ & 4.3 \\
\hline 魚沼市 & 97.8 & 101.2 & 3.4 \\
\hline 湯沢町 & 95.9 & 97.8 & 1.9 \\
\hline 南魚沼市 & 97.6 & 101.5 & 3.9 \\
\hline 津南町 & 97.2 & $\underline{103.7}$ & $\underline{6.5}$ \\
\hline 十日町市 & 97.9 & 99.4 & 1.5 \\
\hline 上越市 & 98.0 & 96.6 & $\triangle 1.4$ \\
\hline 妙高市 & 91.4 & 96.3 & 4.9 \\
\hline 采魚川市 & 91.5 & 96.3 & 4.9 \\
\hline 佐渡市 & 92.3 & 92.6 & 0.3 \\
\hline 県計 & 95.6 & 98.3 & 2.7 \\
\hline
\end{tabular}

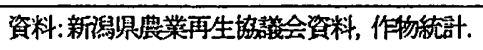

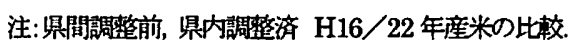

る. 加工用米に独自の1万円 $/ 10 \mathrm{a}$ の助成を行う新舄市 を筆謴に，いずれの市町村も加工用米に熱心に取り組 む. 他方、マイナスとなった中越地域の市町村は, 基 本的には中越地震および中越沖地震の被災地である.

そこでは農地復旧の遅れや震災を契機とした離農等に よる作付减とともに「コメによる転作」に当たっての 地域内合意や新規需要米で求められる「販路確保」等 の取り組みの遅れが推察される.これら地域でも近年, 取り組みが始まっていることを含めれば，この間新潟 が，全県を挙げて「コメ作付面積の確保」を志向し， その結果として加工用米およひ新規需要米の取り組み 
表 7 加工用米およひ新規需要米の取り組み舟

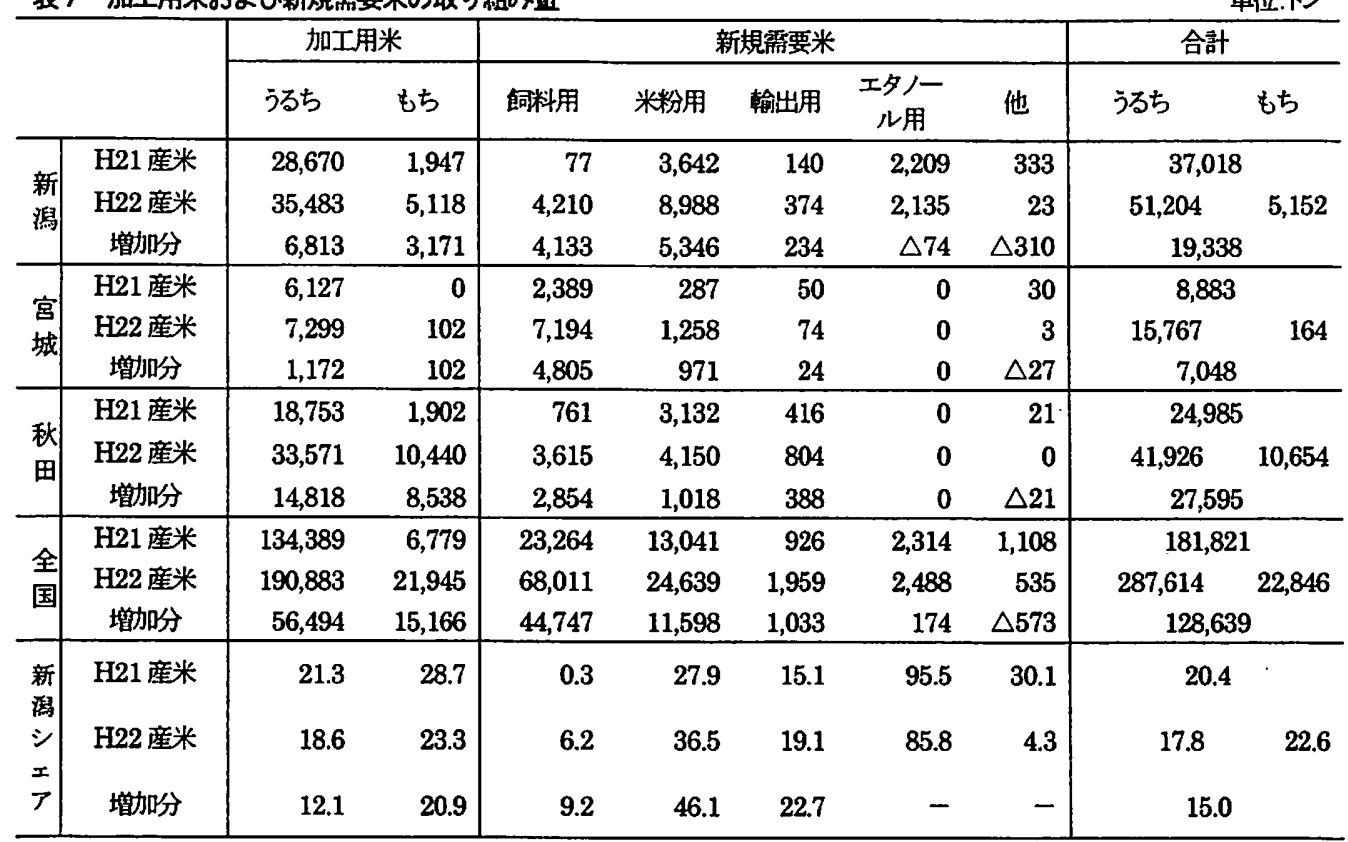

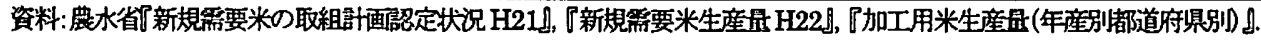

が加速したことが推察される.このことは，反面，「コ メによる転作」が本来プロダクト・アウト的な展開と いう性格を持ち，たまたま事故米事件とその延長とし ての米トレサビ法の施行による輸入MA米需要のシフ トという「追い風」と合致したという側面が否定でき ない.

表7からは，この間の加工用米および新規需要米の 搪大が新潟を筆頭に，全国的に広がっている状况が示 される. 新潟県は，加工用米の $19 \%$ ，新規需要米の $16 \%$ を占め, いずれも全国トップのシェアとなっている. H 21/22の間に限机ば，他県の追いつきや加工用もち米を 增加させる秋田県, 飼料用新規需要米に取り組む宮城 県や山形県等の新舄を超える動きも出てきている.

\section{5. 加工用米・新規需要米の可能性と限界}

先に「コメによる転作」がマーケット的には，事故 表 $8 \mathrm{MA}$ 米の用途別数襾の推移単位: 万トン

\begin{tabular}{r|r|r|r|r}
\hline & $19 R Y$ & \multicolumn{1}{|c|}{20} & \multicolumn{1}{|c}{21} & \multicolumn{1}{|c}{22} \\
\hline 主食用 & 11 & 10 & 8 & 8 \\
加工用 & 37 & 37 & 21 & 21 \\
援助用 & 8 & 12 & 20 & 14 \\
飼料用 & 58 & 66 & 25 & 42 \\
\hline 計 & 114 & 125 & 74 & 85 \\
\hline
\end{tabular}

資料:農水省「最近の米をめぐる関综資料」2010 年.
米事件とその延長としての米トレサビ法の施行による 輸入MA米需要のシフトという「追い風」に硛打ちされ たものであると述べたが，「コメによる転作」の可能 性を占う上では，MA米をめぐる情効について吟味する 必要があろう. MA米は，新規需要米とは飼料用でも米 粉用でも競合し合い，また加工用米とは，ほぼ全ての 販売先で競合する.

表8で示したように，この問，加工用に出回るMA米 は，平成19年産の 37 万トンから平成 22 年産の 21 万トン へ16万トンも减少しており，この間，飼料用も同じく1 6万トンの減少なので, これが全て国内産で置き換わっ ているとすれば32万トンもの国内需要が創出されたこ とになる (MA米全体でも29万トンの减少)。前出表 7 で示される加工用米およひ新規需要米の拡大分は 13 万 トン弱なので, 残りを埋めたのが短期的には流通在庫 の圧縮であったと仮定しても，それらが掃けたあかっ きには，そこには20万トンに及ぶ「伸び代」が用意さ れていることになる.これが今後の「コメによる転作 の」拡大可能性であり，このままの状祝が続くなら， 末だ抗大の余地が残るといえる（同時に上限むそこま でという見方もありうる）。また，秋田等で急速に進 む加工用もち米であるが，売渡数量からみれば, MA米 の売却は60,000トン超 (平成19年) から7,000トン (平 成22年）にまで減少しており，その差5.3万トンが需要 
表9 MA 米の販売 (売渡し) 状況単位:トン,円/トン

\begin{tabular}{|c|c|c|c|}
\hline & $\begin{array}{c}\text { 落札(決定) } \\
\text { 数盟 }\end{array}$ & $\begin{array}{c}\text { 落札(売渡) } \\
\text { 価格 }\end{array}$ & 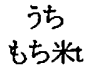 \\
\hline H17 産 SBS & 100,000 & 222,485 & _ \\
\hline H17 産一般 & 578,578 & 54,273 & \\
\hline H18 産SBS & 100,000 & 257,905 & 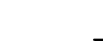 \\
\hline H18産一般 & 578,416 & 61,696 & \\
\hline H19 産 SBS & 100,000 & 243,443 & \multirow{2}{*}{61,836} \\
\hline H19 産一般 & 710,550 & 65,518 & \\
\hline H20 産 SBS & 100,000 & 241,057 & \multirow{2}{*}{43,242} \\
\hline H20 産一般 & 581,000 & 89,523 & \\
\hline H21 産 SBS & 100,000 & 230,784 & \multirow{2}{*}{10,956} \\
\hline H21 産一般 & 578,210 & 67,679 & \\
\hline H22 産 SBS & 37,226 & 194,161 & \multirow{2}{*}{6,928} \\
\hline H22 産一般 & 640,482 & 65,189 & \\
\hline H23 産 SBS & - & - & - \\
\hline H23 産一般 & 56,000 & 72,405 & - \\
\hline
\end{tabular}

資料:農水省「MA一般翰入米入札結果の概要了「輸入米に係引S BSの結果の概要了各月号.

注:価格は各月(SBS は非破碎精米)加重平均価格の加重平均， H23は第2回までの值

純増分となるが，国内産加工用米は1.5万トンの搪大に とどまっており，旧自主流通米を含む需要拡大の可能 性もはらむ.

ただし表9に見るように, MA米の売り渡しは，現在 まで「鿓調」に行われており，加工用等でなければ， 「他の用途として国内のどこかに流通しているもの と推測される. 確かに, 米トレサビ法の開始前後より, これまでとは様相を異にした入札状况が生まれてお り，平成22年産では，毎年上限の10万トンの落札が常 識だったSBS米においても予定数量の $10 \%$ 程度しか落 札されない状㫛が続き，価格を下げても売れず，つ には年計で3.7万トンの落札しかなかったことは画期的 である.それだけ加工や外食等の業務用輸入米への需 要が減少していることは明らかである（ただし，その
穴埋めをMA一般で行っており，それらはむしろ主食用 を含めた国内のどこかで流通している）。それら需要 の一部が国産米にシフトしているのは間違いないが, 同時にSBSでも200円／kg以下，MA一般では60〜70 円 $/ \mathrm{kg}$ 政府売り滛し価格に対抗するには，かなりの 低価格対応を迫られる. 例えば，米菓大手の中で国産 米への切り替えを明言しているのは未だ少数で，多く の業者の事故米以降の原料調達方針は，あくまで「調 達ルートの多様化によるリスク分散」である. そのた め, そこでの国産 (各県産) 米への需要増加も多様な 調達先のひとつに過ぎない.

また，米トレサビ法開始以前のMA米需要は，「先食 いのための見かけ上の需要という側面も否定できな い9). 更には，今後の原料米需要は最終的には消費者 の原料原産地へのこだわりによる. 米トレサビ法の認 知度が低、現状と合わせ，消費者志向に依存する国産 米需要の足腰は安定感のあるものとはいえまい，米粉 調整品・半加工品の利用の場合の非表示やHPでの周 知・店頭での口頭説明等を認める制度的〔拔け穴】， あるいは味㫮業界等の今回対象とならなかった業界で のMA米使用もあり，全体としてのMA米需要の置き換 えがどの程度進むかはいまだ混沌としている.

すなうち，MA米の代替としての国産加工用米・新規 需要米の需要は一定の可能性を持つが, その需要をつ かむには，現行の制度下での新たなMA米との競合に勝 つ必要があり，そのためには，一定の価格対応も必要 となってこよう. 前出表 9 からは, MA米の政府売り渡 し価格が，一般米で70円 $/ \mathrm{kg}(4,200$ 円 $/ 60 \mathrm{~kg}) ， \mathrm{SB}$ $\mathrm{S}$ 米でも $200 \mathrm{H} / \mathrm{kg}(12,000 \mathrm{H} / 60 \mathrm{~kg})$ 程度となってい ることが示されており，MA代替として加工用米およ ひ新規需要米に取り組さ場合，表10に示した通り，生 産者は，反収 4 万円～ 8 万円と主食用米の $1 / 3 \sim 1 / 2$ を

表 10 加工用米・新規需要米の生産者手取りイメージ

\begin{tabular}{|c|c|c|c|c|c|}
\hline & & \multicolumn{2}{|c|}{ 加 工用米 } & \multirow{2}{*}{ 米 粉 用 } & \multirow{2}{*}{ 飼 料 用 } \\
\hline & & & MA 代替 & & \\
\hline \multirow{3}{*}{$\begin{array}{c}60 \mathrm{~kg} \\
\text { 当(円) }\end{array}$} & 販売代金 & $7,000 \sim 9000$ & $4,000 \sim 5,000$ & $1,500 \sim 1,600$ & $1,300 \sim 1,400$ \\
\hline & 流通経掏等 & $2,500 \sim 3,000$ & 2,000 & 750 & $1,300 \sim 1,800$ \\
\hline & 収入 & $4,500 \sim 6,000$ & $2,000 \sim 3,000$ & $750 \sim 850$ & $\triangle 500 \sim 100$ \\
\hline \multirow{4}{*}{$\begin{array}{l}10 \mathrm{a} \text { 当 } \\
\text { (円) }\end{array}$} & 反収 & 570 & 570 & 570 & 570 \\
\hline & 金積 & $42,800 \sim 57,000$ & $19,000 \sim 28,500$ & $7,100 \sim 8,100$ & $\triangle 4,800 \sim 1,000$ \\
\hline & 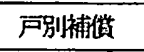 & 20,000 & 20,000 & 80,000 & 80,000 \\
\hline & 生産者手取 & $62,800 \sim 77,000$ & $39,000 \sim 48,500$ & $87,100 \sim 88,100$ & $75,200 \sim 81,000$ \\
\hline
\end{tabular}

资料:全罢にいがた瓷料(H23 年 1 月). 
覚悟せねばならない10．「コメによる転作」が進展す れば, その分, 主食用米と足したトータルの販売単価 は低下し，その対応のためには全体としての低コスト 化が欠かせない：新潟県では，戸別所得補偵制度開始 後も，集楁営農の組織化や法人化が進むが，それは， これら状况のもとで稲作所得の低下が見通される中 で「転作」を含めた低コスト稻作生産の担い手とし て一定規模以上の組織动必要とされる状祝を反映した ものといえようい。

\section{6. まとめ}

以上，述べてきたことを整理して結論としたい，新 潟県における戸別所得補償制度への参加意向は比較的 強く，その背景として米販売の不振およびそれに伴う 生産目標数量配分の縮小に対する危機感を指摘でき る. 以前のように,「作れば必ず売れる新舄米」とい う状況にはない中で，あえて生産調整に参加せず「コ メの所得補偵交付金」を受け取らないという選択は， 販路確保や販売単価維持に相当の自信がある場合に 限られ，そのリスクは経営規模が大きくなるほど高ま りかねない，そのため，制度開始後の生産調整の状况 は，短期的には184haの過㮃作付增となったが，その 中身は, 20a未満の飯米農家および県間調整枠縮小に よるもので, 販売農家に限れば参加件数は却って増加 している.

ただし魚沼の特定地域に典型的な動きがみられる ように, 生産目標数量の配分を減らされたところで, 他の作目への転換が見通せない地域では，水稲を作付 寸る他なく，しかも，加工用米や新規需要米ではコス 卜割をおこす場合，それは自動的（好むと好まざると） に生産調整政策の外に出てしまう。これら層を制度内 に取り込むには，所得補顀の水準全体の引き上げ，あ るいは少なくとも加工用米等と（魚沼米水淮の）主食 用米の価格差を埋める補償の上積みが必要であり，飯 米農家の制度への取り込みとともに制度抗充が必要 であろう。

同時に中長期的には，コメ以外の「戦略作物」の定 着も課題であるが，それらが進まない中，特徵的な動 きとしては，加工用米・新規需要米，すなわち「コメ による転作」の拡大が目立つことになった。この「コ メによる転作」は地域的には，新潟県央から下越南部 にかけて大きく進展しており，そこでは生産目標数量
の減少を受けて，それでもコメ作付維持するための手 法として取り組まれていた.これら「コメ回师」を可 能とする市場的条件は，原料原産地表示颚務制度が開 始される中で急速に進むMA米から国産米への需要シ フトであった. MA米は, 新規需要米・加工用米と常に 競合関係にあり，事故米事件の記憶が風化しきってい ない現下の需給状况は，むしろコメ加工業者における MA米需要低下とその寒返しの国産米需要拡大を基調 とするが, これまで水面下（表示義務のないままで） で行われてきた外国産米使用が. 原料原産地表示制度 のもとで明示され・表に出ることにより，今後の外国 産米使用についての消费者認知・需要定着が促進され る可能性もあり，需給の行方は見通せない．

「コメによる転作」がMA米と競合し，それを食う形 で拡大されているうちは，まだしも，MA米需要が一定 回復する局面にでもなれば，そこでの「コメによる転 作」拡大は，主食用米本体を食うことになりかねず， 加工用米等により食われたMA米が主食用を含めた市 場のどこかに流通する可能性とともに，「転作」の本 来の目的からすると本末転倒となる事態が危惧され る. 特に「もち米」は，従来，主に自主流通米として 扱われてきたものであり，それがMA米に食われて縮小 してきたこれまでの経緯を踏まえるならば、MA米需要 の置き換えは，むしろ主食用米で取り組むべきであり， また，秋田県等で進咖工用もち米の取り組みもそこ のみを見れば取り組みの前進と評価し得るとしても， それが (他県産) 主食用もち米と競合する場面を想定 しての慎重な評価・対応が求められよう.

いずれにせよ, MA米の代替ニーズをターゲットに加 工用米および新規需要米に取り組さ場合, MA*米の低い 価格水準を前提に、それとの競合に勝つ必要があり， そのためには，一定の価格対応が必要となってくる. その際，流通経費等を差し引いた農家の手取価格は， 飼料用の $\triangle 500 \sim 100$ 円 $/ 60 \mathrm{~kg}$ を底に、高くてもMA米 代替 $2,000 \sim 3,000 \mathrm{P} / 60 \mathrm{~kg}$ となり，平均的な反収水準 では「物財費も出ない状況である. だからこそ，新 規需要米 8 万円 $/ 10 \mathrm{a}$ ，加工用米2万円 $/ 10 \mathrm{a}$ の戸別所得 補償 (水田活用交付金) による支えが大きな意義を持 つともいえるが, それがあっても現行水準では，MA米 代替加工用米の生産者手取り水淮は低く，特に魚沼な ど生産コストの高い，主食用米との価格差の大きな地 域では取り組みを拡大寸る条件は少ない，また，新規 
需要米 8 万円 $/ 10 \mathrm{a}$ の交付金の存在は大きいが，これを 前提とした販売価格は，米粉用米での価格低下（5,000 円程度 $\rightarrow 1,500$ 円），飼料用米での流通経費を差し引け ば赤字となる等, 極めて低水淮であり, 財政負担・予 算の持続性を含めて制度的には不安定な側面を持つも のと評価されよう。

注

1）ここで，新瘦を「水稲単作地带の典型りと位置付けたが， シンポジウム全体のテーマである「東北農業欇造」を論 じるにあたり，他県との違いについては注意を要する. 周知のごとく新舄は一般に北陸に属し, 耕種部門の㖘業 総産出額のうち米が占める割合は，新潟の7割超に対し， 東北各県は，秋田・宫城の6割台〜青森の2割台まで多 様で（『生産展業所得統部』平成21年），既に稲作の 位置付けが小さい地域も多く含まれる. しかしながら， それでも土地利用という点で見れば, 東北十新舄の水田 のある全256市町村のうち耕地面積の50\%以上を水稲 が占める市町村が136 (53\%)，田本地面積の70\%以上 を水稻が占める市町村が148（58\%）を占め（『作物統 計』平成22年），そこでは，新潟と同様の論理が偟く 可能性は否定できない.この点について, シンポジウム 当日にコメントを頂いた冬木勝仁氏，また九州等の他地 域でも「米による転作」拡大は共通の論理である点を指 摘頂いた磯田宏氏に記して感謝申し上げる.

2）新舄県稻作生産組織協議会资料2010.2より.

3）この間の新舄の米価をめぐる状况については，伊藤 [1][2]を参照のこと.また新舄米を頂点とした産地品種 銘柄の序列樺造については小池[3]に詳しい.

4）このような，新潟県産米の值引き販売のあおりを食うの が, 2番手コシヒカリ (新潟以外の北陸・会津) あるいは 非コシBランク米上位 (東北) 等の2番手・3番手産地で ある. 図2に示すように, 低下する新舄米と価格序列の最 下位にある北海道米の間に挟まった東北米にツケ＝「販 売残」を回すことになる. 21年産米の場合, 全国持越し 在庫34万トンの内訳は, 宮城県7.8万トン, 山形県5.3万 トン, 秋田県5.1万トン，岩手県3.5万トン，青森県 3.2 万 トン, 雷山1.6万トンとされ，これら小計で26.5万トン

（75\%）を占める（食品産業新聞社『米と流通』2010年 9月号, p18より).

5）平成22年度「新舄県米政策改革基本方針」の政訂により。 基本方向として「非主食用米の安定供給体制を確立する とともに，土地利用型作物の生産桩大や園芸複合化の取 ・組搪大を推隹」との文言が始めて加わる。

6）尚，平成21年産の生産調整不参加10,722者の楎成比は, 20 a末满は $35 \% ， 20 \mathrm{a} \sim 1 \mathrm{ha}$ は $31 \% ， 1 ２ \mathrm{hal} 13 \% ， 2$ 3haは $11 \%$, 3〜4haは $5 \%$, 4ha以上は $5 \%$ とっており， 大規模㖘家の比率は極好低い：また，これらの生産調 整不参加者の過半は新舄市近郊の旧4市町村が占めてお り、いわは固定層となっている.

7) 津南町では，国営苗場地区国場整借事業の储還金が3.5万 円/10a，南魚沼市では，土地改良区の水利费通常賦課金 が4.8万円/10aという事例がある.

8）逆に，地域での取り組みが進み，作付割合の大きい市町 村では総じて単収水淮も高い傾向を示寸，新舄県内では， （旧越路町を中心に）長岡市（田本地面積の6.5\%），燕 市 (同9.1\%)，上越市 (同8.2\%)，田上町 (同7.5\%) では，農協のカントリ一集荷等も含め支援体制が夼実し ており, 单収水蕉も $150 \sim 170 \mathrm{~kg} / 10 \mathrm{a}$ 台の平均值となっ ている.

9）2011年 7月の原料原産地表示開始以前に仕入れた原料米 は，「産地等が特定されない埸合」もあり得るとして。 それらを使用する際には表示矝務は発生しない，そのた め 7 月以前に早めに調達し，それを以降の生産に充てる という手法がまかり通ることになる．7月に開始された 原料原産地表示のもとでも，そのような製品は表示なし のまま流通されているのが実態であり，その意味では，

「7月以前のMA米」は原料原童地表示義務を免れるため の「大事な玉」であり，それと7月以降の需要娍の差がそ のまま国産米需要となる訳ではない.

10）ここでの価格水準は，地域における6次産業的なつなが り等により，製品段階て付加価值化がはかられることを もって相対的に高価格で買い取るというような契約栽培 方式は想定していない，そのような展開が，例えは新舄 では一部の清酒業界や米菓・米粉業界で行わ扎ているの も事実である. また山形県での蚼料用米の取り組みは小 沢[5]に詳しいただし，これらの取り組みとは丵って「新 規 て参入する場合を想定したのがこの表の考え方であ る. 逆にいえば，新規参入が低洒格対応て進むことで， 既存の取り組みを阻害する局面もありえよう.

11）この点について，宮武[4]では，新潟県の集落営農組織 の特徽として「今後は転作部門を含めた担い手としての 活躍が期待されている」と指摘しており，上中越地域の 大豆を中心とした組織的な転作対応が下越地域にも波及 することを展望している．まさにそのとおりと評価する が，下越の一部地域では，そこでの「転作」がコメを中 心とすることから，それは同時に主食用米をひっくるめ た「稻作維持」のための生産組織化という流れが形成さ れているともいえる。

引用文献

〔1]伊藤亮司「米価変動の要因分析』『農業と経済』11月号,2010 年,pp.5-16.

[2]伊藤克司「コメ戸別所得補㑽モデル対策下における米価問

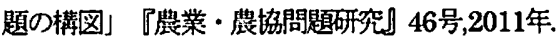

[3]小池晴伴「流通再編下における系統整協の米販売機能に関 する研究」『酪哇学園大学紀要』,人文・社会科学編 24(2) 2000年, 187-247.

[4]宮武恭一「北陸地域の集落営農の特徽と今後の課題]『水 田・烟作経営安定対策下における集落営震組織等の動向と 今後の課題』 経営安定プロジェクト研究资料第 2 号, 2009年, pp.69-79.

[5]小沢互・吉田宣夫編『飼料用米の载培・利用』創森社, 200 9 年,pp.1·131.

〔2012年1月15日受理〕 